\title{
PCL/ZnO Bio-friendly Films as Food \\ Packaging Material.Thermal and morphological analysis
}

\author{
Rivaildo Miranda de Andrade ${ }^{1}$, Sandro Manoel da Silva Júnior ${ }^{1}$, \\ Suellen Veloso Corte Real Coutinho ${ }^{1}$, Nichollas Guimarães Jaques ${ }^{1}$, \\ Hermano de Vasconcelos Pina ${ }^{2}$, Bruna Gabriella Rodrigues ${ }^{2}$, \\ Marcus Vinicius Lia Fook ${ }^{2}$, Pollyana Caetano Ribeiro Fernandes ${ }^{3}$, \\ Andreas Ries ${ }^{4}$, Renate Maria Ramos Wellen ${ }^{1}$
}

\footnotetext{
${ }^{1}$ Materials Engineering Department, Federal University of Paraiba, 58051-900, João Pessoa, Paraíba, Brazil.

${ }^{2}$ Materials Engineering Department, Federal University of Campina Grande, 58429-900, Campina Grande, Paraíba, Brazil.

${ }^{3}$ Renewable Energy Department, Federal University of Paraiba, 58051-900, João Pessoa, Paraíba, Brazil.

${ }^{4}$ Electrical Engineering Department, Federal University of Paraiba, 58051-900, João Pessoa, Paraíba, Brazil. e-mail: rivaildomiranda@ hotmail.com, sandromsjunior@gmail.com, suellen_veeelooosooo@ hotmail.com, wellen.renate@gmail.com, ries750@yahoo.com.br, hermanovp@gmail.com, bruhrodrigues@gmail.com, marcus.vinicius@ufcg.edu.br, pollyana@cear.ufpb.br
}

\begin{abstract}
Films of Poly( $\varepsilon$-caprolactone) (PCL) and PCL/Zinc Oxide (ZnO) were obtained by solution processing. Thermal behaviour and morphological structure were analysed by means of Thermogravimetry (TGA), Differential Scanning Calorimetry (DSC), Optical Microscopy (OM) and Scanning Electron Microscopy (SEM). The addition of $\mathrm{ZnO}$ to $\mathrm{PCL}$ decreased the degradation temperature about $50-70^{\circ} \mathrm{C}$; the films are thermally stable up to $200^{\circ} \mathrm{C}$, making them suitable for packaging hot grilled chicken. ZnO did not promote significant alterations of the PCL fusion and melt crystallization, however the crystallinity increased; probably $\mathrm{ZnO}$ acts as nucleating agent during PCL crystallization as OM images showed greater amount of small spherulites on $\mathrm{PCL} / \mathrm{ZnO}$ films. According to SEM, the methodology utilized is adequate for producing films in concentrations up to $5 \% \mathrm{ZnO}$.
\end{abstract}

Keywords: PCL, ZnO, Thermal behaviour, Morphological structure.

\section{INTRODUCTION}

Nowadays polymers have been used for sundry purposes; many industrial sectors use them to manufacture products with specific properties. Automobile, textile, packaging, hospital and health care, are examples of industries that have successfully employed polymers. However, most of the traditional polymers have a slow degradation rate, a fact that has generated garbage accumulation and serious environmental problems, becoming its management and reduction a target for the polymer engineers [1-4]. This scenario favores the production of biodegradable polymers, natural ones and those obtained from renewable sources. These polymers degrade easily in presence of microorganisms generating nontoxic products to man and environment [5-7].

A quite important and biodegradable polymers is Poly( $\varepsilon$-caprolactone) (PCL). PCL is a synthetic aliphatic polyester fabricated from petroleum sources. Its excellent biodegradability and biocompatibility as well as bioreabsorbability have promoted its applications in many fields, such as packing, tissue engineering materials, drug delivery, controlled release carrier, surgery, and so on.

The market demand for biodegradable polymers has been increasing rapidly, which is highly encouraged by environmental management policies. After disposal, PCL is rapidly biodegraded ( 6 months in suitable medium), producing nontoxic low molecular weight compounds [3-9].

In order to further improve the properties of PCL, the incorporation of other functional additives into the polymer has received more and more attention. In this work PCL/Zinc oxide ( $\mathrm{ZnO})$ compounds were prepared by solution processing, with $\mathrm{ZnO}$ concentration ranging from $0 \%$ to $15 \%$ (weight). $\mathrm{ZnO}$ is not only a well-known semiconductor material for solar energy conversion, optoelectronic devices, piezoelectric generators, etc., but also an important additive in rubber and plastic industry for the purposes of transferring an- 
tibacterial, antisepticizing, UV-shielding, and deodorizing properties [10-12].

The objective of this work was the preparation of PCL and PCL/ZnO films and demonstrating their suitability for hot food packing (e.g. hot grilled chicken); the thermal and morphological properties of the films were analyzed. The thermal stability of PCL and PCL/ZnO films was investigated by Thermogravimetry Analysis (TGA), their thermal properties as well as the crystallinity were measured by Differential Scanning Calorimetry (DSC) and the morphological structure was examined by means of Optical Microscopy $(\mathrm{OM})$ and Scanning Electron Microscopy (SEM).

\section{MATERIALS AND METHODS}

\subsection{Materials}

PCL (trade name CAPA 6500) was purchased from Perstorp Winning Formulas (Sweden) and was used without any further treatment. Zinc oxide $(\mathrm{ZnO})$ was purchased from Acros Organics $(99.5 \%$ purity, specific surface area of $28 \mathrm{~m}^{2} / \mathrm{g}$ ). In this work, $\mathrm{ZnO}$ was incorporated into the PCL matrix without using any dispersion agent. Acetone was purchased from Química Moderna (99.5\% purity).

\subsection{Processing of PCL and PCL/ZnO films}

PCL films were produced dissolving PCL pellets in $50 \mathrm{ml}$ acetone, in concentration of $5 \%$ (mass/volume). The mixture was stirred at $40^{\circ} \mathrm{C}$ for 30 minutes; afterwards PCL was completely dissolved. The solution was placed into petri dishes of $15 \mathrm{~cm}$ diameter, followed by oven drying at $40^{\circ} \mathrm{C}$ for 18 hours. PCL/ZnO films followed the same methodology as neat PCL. The $\mathrm{ZnO}$ addition was performed in PCL solution. PCL/ZnO films were produced with 5\%, 10\% and $15 \% \mathrm{ZnO}$ (weight).

\subsection{Thermogravimetry (TG)}

Thermogravimetry analysis was performed on a Shimadzu TGA $60 \mathrm{H}$ unit. Samples of approximately $5 \mathrm{mg}$ were heated in an alumina pan from ambient temperature $\left(\sim 23^{\circ} \mathrm{C}\right)$ to $800^{\circ} \mathrm{C}$ using a heating rate of $10^{\circ} \mathrm{C} / \mathrm{min}$, under argon flow of $50 \mathrm{ml} / \mathrm{min}$.

\subsection{Differential scanning calorimetry (DSC)}

Thermal analysis was performed using a TA Instruments DSC Q20 differential scanning calorimeter, under a nitrogen flow of $50 \mathrm{ml} / \mathrm{min}$ and approximately $5 \mathrm{mg}$ sample weight. A thermal cycle of four stages was used: (1) heating from $25^{\circ} \mathrm{C}$ to $100^{\circ} \mathrm{C}$ (first heating stage); (2) isothermal stage: the samples were held at $100^{\circ} \mathrm{C}$ for 3 min to eliminate any residual crystallinity and erase the previous thermal history; (3) the melt was cooled to $0^{\circ} \mathrm{C}$ (cooling stage) and then (4) reheated to $100^{\circ} \mathrm{C}$ (second heating or reheating stage). All tests were conducted at constant heating and cooling rate of $10^{\circ} \mathrm{C} / \mathrm{min}$.

The mass crystallinity change $\Delta X_{c}$ during the event was estimated, taking into account the heat of fusion of $100 \%$ crystalline PCL, $\Delta \mathrm{H}_{m}{ }^{0}: \Delta \mathrm{X}_{\mathrm{c}}=\Delta \mathrm{H} / \Delta \mathrm{H}_{\mathrm{m}}{ }^{0}$.

Where: $\Delta \mathrm{H}=\mathrm{E}_{0} /\left(\mathrm{w}_{\mathrm{p}} \mathrm{m}_{\mathrm{s}}\right), \mathrm{E}_{\mathrm{o}}$ is the DSC melting/crystallization heat change, $w_{P}$ the polymer fraction and $m_{S}$ the sample mass.

The literature lists two slightly different reference values for the latent heat of fusion of PCL. Mandelkern [13-14] reports the value 142,4 J/g in two of his textbooks; another textbook by Van Krevelen and Nijenhuis [15] quotes the value $148.1 \mathrm{~J} / \mathrm{g}$. In the present work we decided to use the value $145 \mathrm{~J} / \mathrm{g}$, an approximated mean value, as the melting enthalpy of $100 \%$ crystalline PCL.

\subsection{Optical microscopy (OM)}

Optical microscopy images were captured using a Zeiss Axiotech 100; the film surfaces of PCL and $\mathrm{PCL} / \mathrm{ZnO}$ compounds were analyzed without any treatment.

\subsection{Scanning electron microscopy (SEM)}

Scanning electron microscopy images were acquired with a LEO 1430 unit, from Zeiss. The polymer samples were coated with a gold layer in order to avoid the accumulation of charges. 


\section{RESULTS AND DISCUSSION}

The thermal stability of PCL films and its compounds with 5\%, $10 \%$ and $15 \%$ of $\mathrm{ZnO}$ was investigated by thermogravimetry (TG). Figure 1 presents the degree of decomposition versus temperature plots for the compositions analysed in this work. All compositions presented weight loss in a single stage. $\mathrm{ZnO}$ greatly decreases the thermal stability of PCL, as the sigmoides of PCL/ZnO compounds are shifted around $50-70^{\circ} \mathrm{C}$ to lower temperatures, depending on the composition. For films produced with neat PCL, $\mathrm{T}_{0.05}$ (temperature for $5 \%$ weight loss) was observed at $435^{\circ} \mathrm{C}$; the addition of $\mathrm{ZnO}$ to PCL decreased the thermal stability, and the compounds exhibited $\mathrm{T}_{0.05}$ of $379^{\circ} \mathrm{C}, 361^{\circ} \mathrm{C}$ and $358^{\circ} \mathrm{C}$, for compositions with $5 \%, 10 \%$ and $15 \% \mathrm{ZnO}$, respectively. At the end of the experiment residues of 5\%, 9.30\% and $12.00 \%$ were observed, which correspond approximately to the $\mathrm{ZnO}$ content added to PCL. The average degradation rate $\mathrm{C}_{\mathrm{ave}}$ did not significantly change upon addition of $\mathrm{ZnO}$, as can be verified in Table 1 . Therefore it is suggested $\mathrm{ZnO}$ decreases the thermal stability of PCL, changing only slightly its degradation rate.

Table 1: Thermal parameters computed from TGA analysis for PCL and PCL/ZnO compounds. $\mathrm{T}_{0.05}$ temperature for $5 \%$ of weight loss. $\mathrm{T}_{0.95}$ temperature for $95 \%$ of weight loss. $\mathrm{C}_{\text {ave }}$ evaluated for weight loss ranging from 0.1 to 0.9 . Residue $(\%): \mathrm{ZnO}$ content at the end of the experiment.

\begin{tabular}{l|l|l|l|l}
\hline $\begin{array}{l}\text { ZNO } \\
(\%)\end{array}$ & $\begin{array}{l}\mathrm{T}_{0.05} \\
{\left[{ }^{\circ} \mathbf{C}\right]}\end{array}$ & $\begin{array}{l}\mathrm{T}_{0.95} \\
{\left[{ }^{\circ} \mathbf{C}\right]}\end{array}$ & $\begin{array}{l}\mathbf{C}_{\text {AVE }} \\
{\left[\mathbf{H}^{-1}\right]}\end{array}$ & $\begin{array}{l}\text { RESIDUE } \\
(\%)\end{array}$ \\
\hline 0 & 370 & 435 & 10.44 & -- \\
5 & 291 & 379 & 6.84 & 5.00 \\
10 & 295 & 361 & 9.72 & 9.30 \\
15 & 294 & 358 & 9.72 & 12.10 \\
\hline
\end{tabular}

Figure 2 displays DSC curves for PCL and PCL/ZnO compounds; these curves were acquired during heating (first fusion), cooling (melting crystallization) and reheating (second fusion) at $10^{\circ} \mathrm{C} / \mathrm{min}$. Apparently adding $\mathrm{ZnO}$ to PCL did not promote significant alterations of the fusion nor of the melt crystallization of neat PCL. First fusion, melt crystallization and second fusion events were verified to occur in the same temperature interval for PCL and its compounds. By DSC measurements, no alterations of the PCL thermal stability upon addition of $\mathrm{ZnO}$ could be detected, which is in agreement with the TG curves. Possibly the temperature ranges applied during DSC experiments were low enough to keep the thermal integrity of PCL and PCL/ZnO compounds. DSC parameters for PCL and PCL/ZnO compounds are displayed in Table 2. 


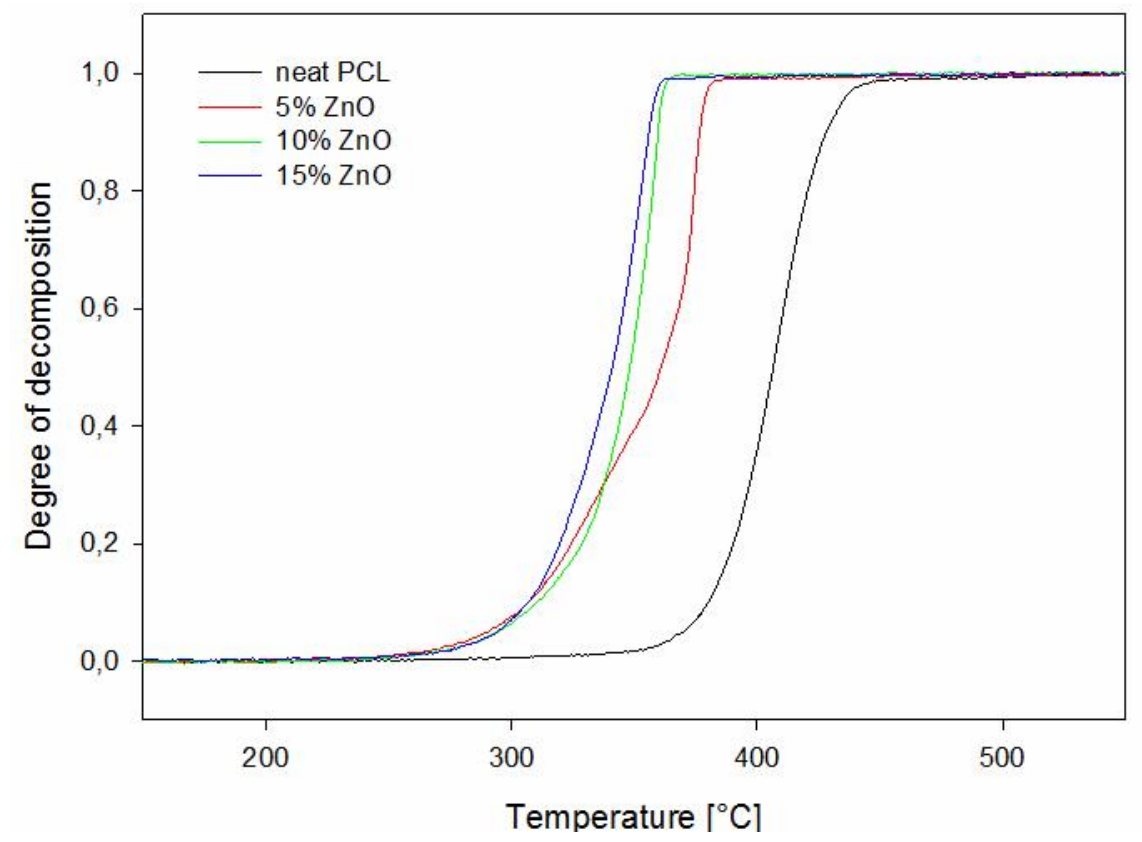

Figure 1: Degree of decomposition versus temperature for PCL and PCL/ZnO compounds. 

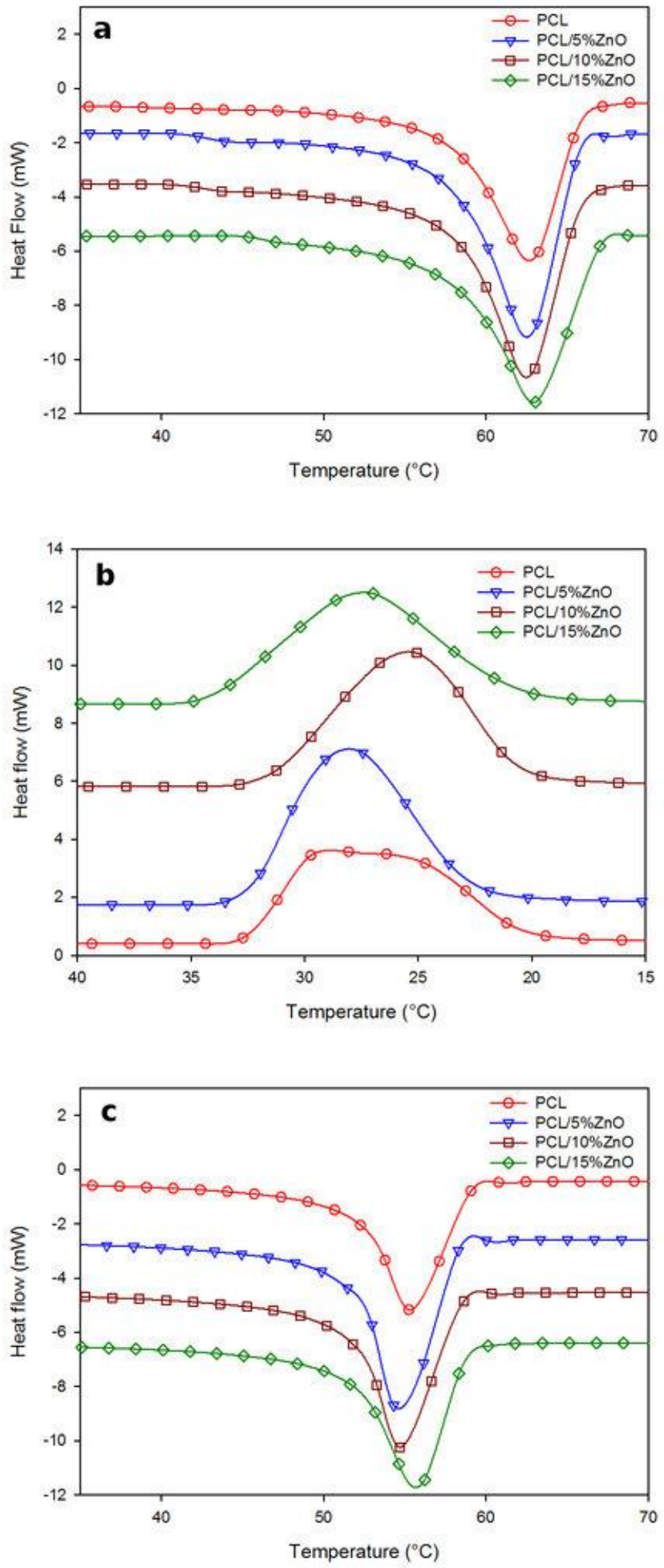

Figure 2: DSC scans for PCL and PCL/ZnO compounds. (a) First heating - melting endotherms, (b) cooling - crystallization exotherms, (c) Second heating - melting endotherms. Heating/Cooling/Reheating at $10^{\circ} \mathrm{C} / \mathrm{min}$. 
Figure 3 shows the molten fraction and relative crystallinity as a function of temperature for PCL and its compounds with $\mathrm{ZnO}$. As can be observed, the fusion curves overlap suggesting PCL fusion mechanisms did not change upon addition of $\mathrm{ZnO}$. A very similar behaviour is observed for the melt crystallization where the overlapping is also verified, in this situation with slight differences. It is a very interesting result, once the PCL thermal stability as well the degradation temperatures are modified upon addition of $\mathrm{ZnO}$ (according TG results) but not the mechanisms involved with fusion and crystallization. It is well known that PCL is a thermally stable polymer. According to the results presented in this work, the PCL stability is kept until around $300^{\circ} \mathrm{C}(\mathrm{PCL} / \mathrm{ZnO})$; at higher temperatures, degradation starts and develops in a single event as commented in the TG section.

Another consequence extracted from DSC results is related to the processing parameters. As neither fusion nor crystallization changed, the processing of PCL and PCL/ZnO compounds may occur under equal conditions.
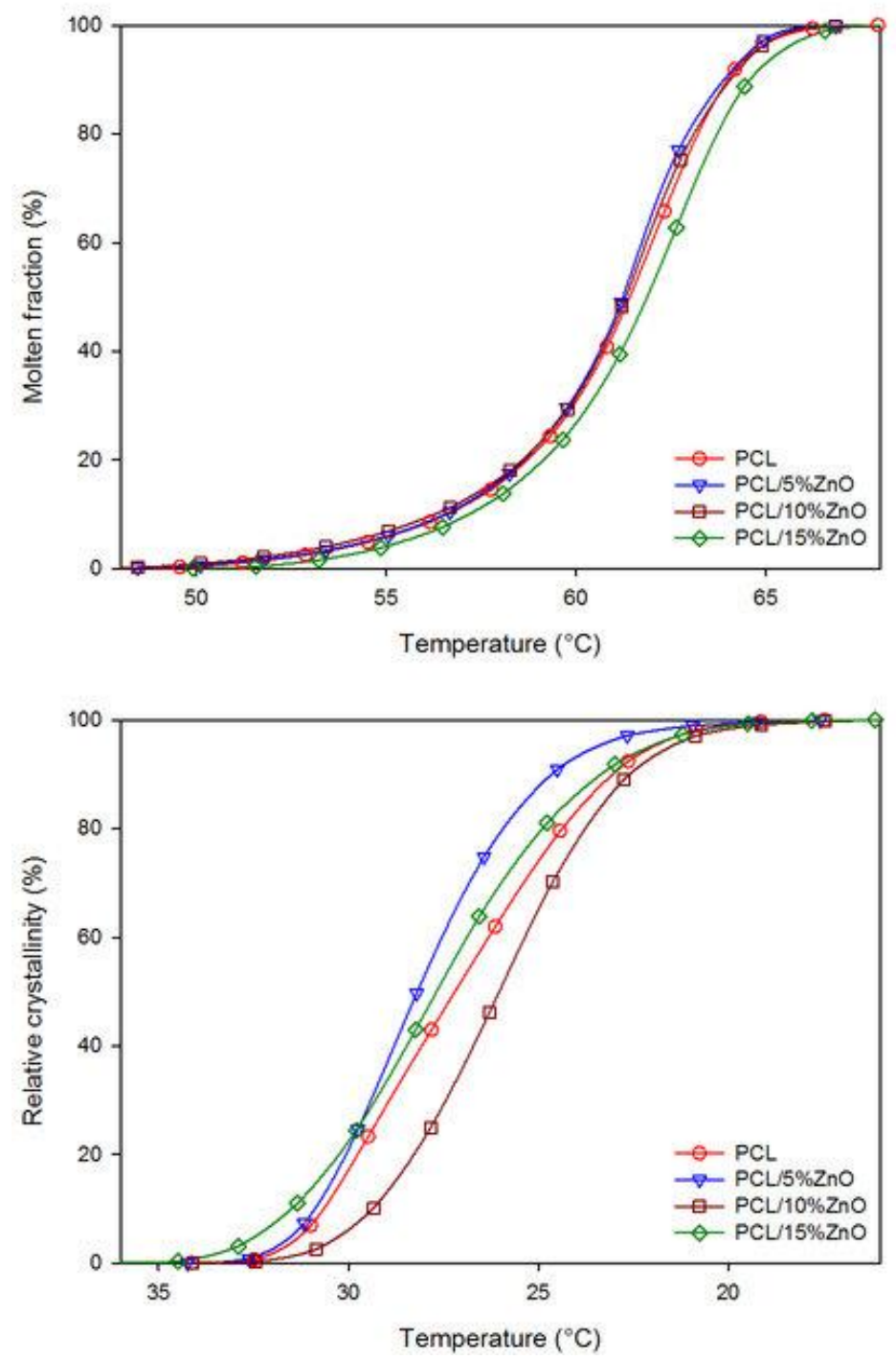

Figure 3: Molten fraction and relative crystallinity versus temperature for PCL and PCL/ZnO compounds. 
Figure 4 shows the fusion rate versus molten fraction and crystallization rate versus crystallized fraction for PCL and PCL/ZnO compounds; all compositions presented quite similar fusion rates, which have a bell-shaped behaviour with the beginning and the ending of the fusion occurring at lower rates and the intermediary (gross) mass melting at very fast rate; the same arguments are valid for melt crystallization, but for $\mathrm{PCL} / \mathrm{ZnO}$ compounds the curves are somehow subtly higher than that for neat PCL. Higher crystallization rates are observed for PCL/ZnO compounds (Table 2), nevertheless the bell-shaped behavior is clearly identified.
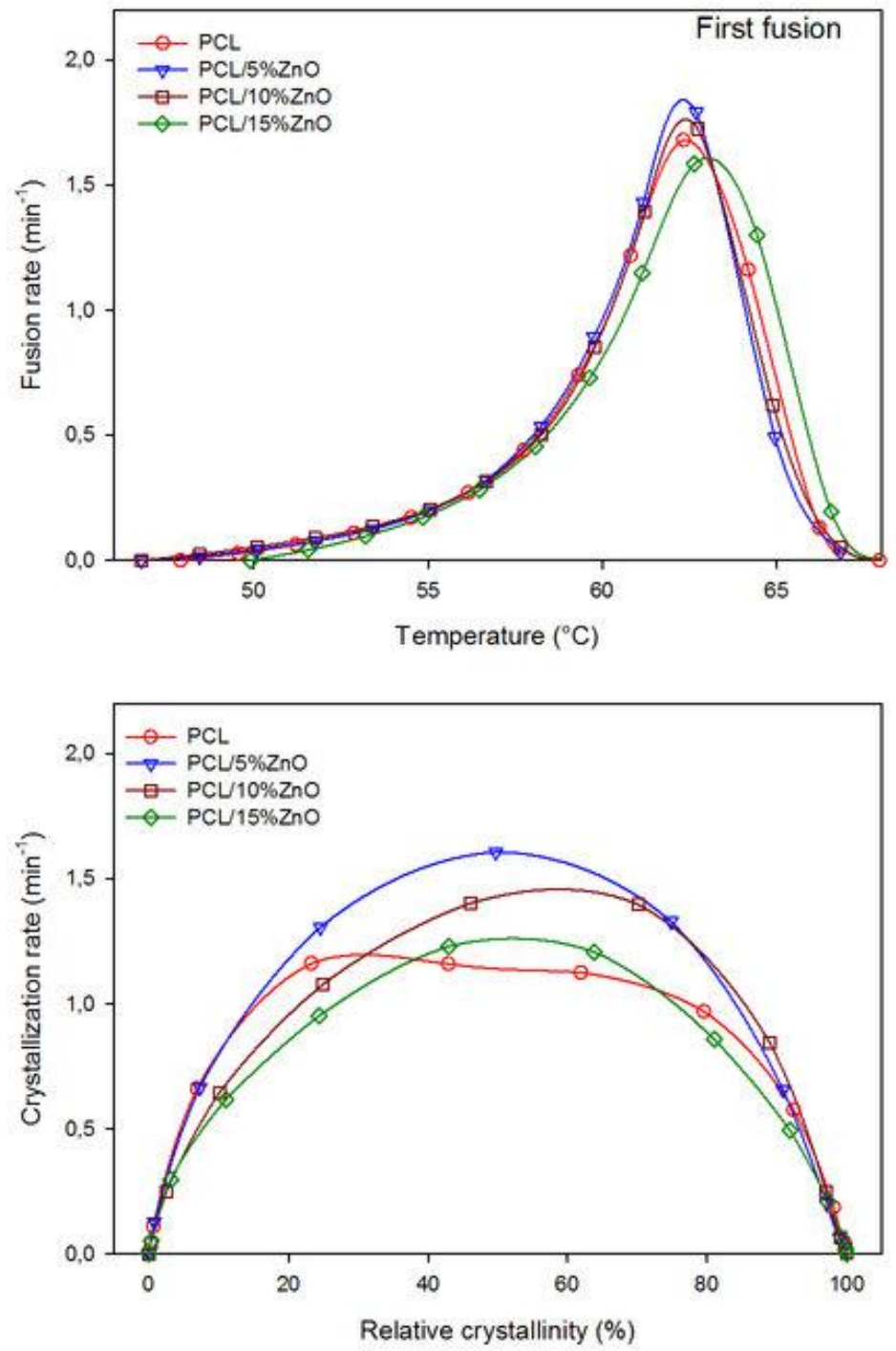

Figure 4: Fusion rate versus molten fraction and crystallization rate versus crystallized fraction for PCL and PCL/ZnO compounds.

The crystallinity $\left(\Delta \mathrm{X}_{\mathrm{c}}\right)$ developed during heating/cooling/reheating scans increased upon $\mathrm{ZnO}$ addition. It is probable that $\mathrm{ZnO}$ acts as nucleating agent, promoting PCL crystallization, as further supported by optical microscopy images (Figure 5). A significant decrease in PCL spherulitic size upon addition of $\mathrm{ZnO}$ can be observed. 
Table 2: DSC thermal parameters of PCL and PCL/ZnO compounds. $\mathrm{T}_{\mathrm{m}}$ : melting peak temperature. $\mathrm{T}_{\mathrm{c}}$ : crystallization temperature. $\mathrm{c}_{\max }$ : maximum crystallization rate. $\tau_{1 / 2}$ : time to reach $50 \%$ of developed crystallinity (crystallisable mass). $\mathrm{X}_{\mathrm{c}}$ : degree of crystallinity

\begin{tabular}{|c|c|c|c|c|c|c|c|c|c|c|c|c|}
\hline \multirow[b]{3}{*}{$\begin{array}{l}\text { Compo- } \\
\text { sition }\end{array}$} & \multicolumn{12}{|c|}{ EVENT } \\
\hline & \multicolumn{4}{|c|}{ FIRST FUSION } & \multicolumn{4}{|c|}{ MELT CRYSTALLIZATION } & \multicolumn{4}{|c|}{ SECOND FUSION } \\
\hline & $\begin{array}{l}\mathrm{c}_{\max } \\
\left(\min ^{-1}\right)\end{array}$ & $\begin{array}{l}\mathrm{T}_{\mathrm{m}} \\
\left({ }^{\circ} \mathrm{C}\right)\end{array}$ & $\begin{array}{l}\tau_{1 / 2} \\
(\min )\end{array}$ & $\begin{array}{l}\Delta \mathrm{X}_{\mathrm{c}} \\
(\%)\end{array}$ & $\begin{array}{l}\mathrm{c}_{\max } \\
\left(\min ^{-1}\right)\end{array}$ & $\begin{array}{l}\mathrm{T}_{\mathrm{c}} \\
\left({ }^{\circ} \mathrm{C}\right)\end{array}$ & $\begin{array}{l}\tau_{1 / 2} \\
(\min )\end{array}$ & $\begin{array}{l}\Delta \mathrm{X}_{\mathrm{c}} \\
(\%)\end{array}$ & $\begin{array}{l}\mathrm{c}_{\max } \\
\left(\min ^{-1}\right)\end{array}$ & $\begin{array}{l}\mathrm{T}_{\mathrm{m}} \\
\left({ }^{\circ} \mathrm{C}\right)\end{array}$ & $\begin{array}{l}\tau_{1 / 2} \\
(\min )\end{array}$ & $\begin{array}{l}\Delta \mathrm{X}_{\mathrm{c}} \\
(\%)\end{array}$ \\
\hline PCL & 1.722 & 62.8 & 1.29 & 19.1 & 1.189 & 28.9 & 0.64 & 15.8 & 1.774 & 55.8 & 2.38 & 16.4 \\
\hline $\begin{array}{l}\text { PCL/ } \\
5 \% \mathrm{ZnO}\end{array}$ & 1.793 & 62.6 & 1.35 & 23.3 & 1.609 & 28.1 & 0.59 & 19.0 & 1.960 & 55.0 & 2.43 & 19.9 \\
\hline $\begin{array}{l}\text { PCL/ } \\
10 \% \mathrm{ZnO}\end{array}$ & 1.726 & 62.7 & 1.39 & 25.6 & 1.462 & 25.5 & 0.74 & 24.5 & 1.818 & 55.2 & 2.34 & 21.0 \\
\hline $\begin{array}{l}\text { PCL/ } \\
15 \% \mathrm{ZnO}\end{array}$ & 1.653 & 63.2 & 1.16 & 24.2 & 1.276 & 27.5 & 0.78 & 19.8 & 1.642 & 55.7 & 2.30 & 20.7 \\
\hline
\end{tabular}
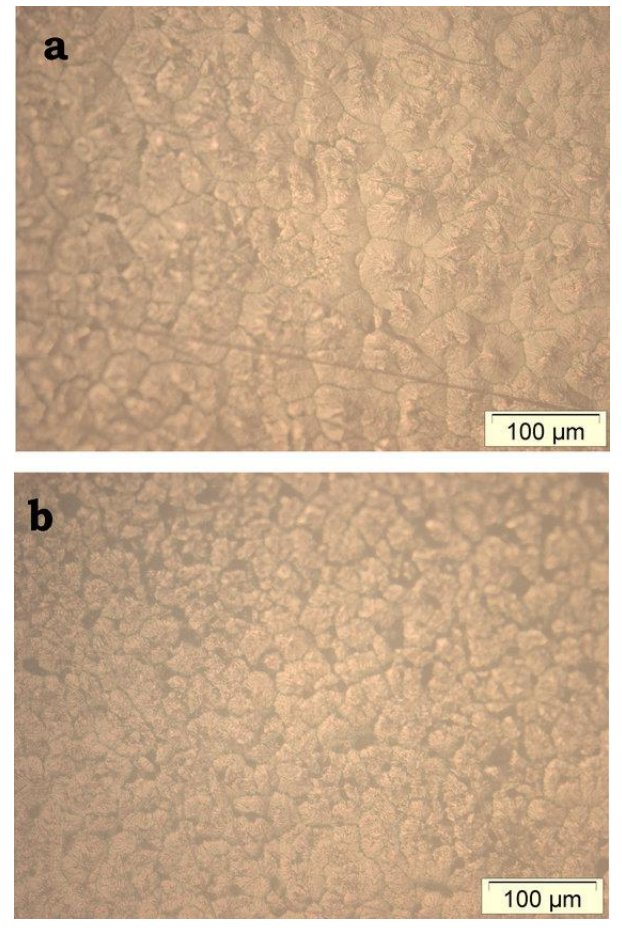

Figure 5: Optical microscopy images of neat PCL (a) and PCL/5\% ZnO (b).

Figure 5 displays optical microscopy images for PCL and PCL/5\% ZnO compounds; spherulites are observed in both images. However, in neat PCL these shperulites are bigger. Possibly $\mathrm{ZnO}$ acts as a nucleating agent during PCL crystallization. In compounds with $10 \%$ and $15 \% \mathrm{ZnO}$ (images not shown), PCL spherulites are lower than they are in compounds with $5 \% \mathrm{ZnO}$. This behavior agrees with the higher crystallization rates for PCL compounds as presented in Table 2. Probably $\mathrm{ZnO}$ particles act as heterogeneities decreasing the nucleation energy and increasing PCL crystallization rates. The literature presents works where the addition of additives, polymers and fibers modify the crystallization mechanisms and the morphological structure of PCL, see for examples bamboo cellulose/PCL composites [5], PCL/SiO 2 [7], PBT/PCL blends [8], PCL/graphite nanoplatelets [9]. 
Scanning electron microscopy images for PCL compounds are presented in Figure 6, these images were captured from gold coated PCL films, no other thermal or chemical treatment was done. In Figure 6(a) a smooth surface is observable, similar to that of neat PCL (image not shown); ZnO seems to be well dispersed in the PCL matrix, which is indicative for high quality films; this also agrees with the residue content evaluated from TG analysis.

However for higher concentrations of $\mathrm{ZnO}$, i.e., films with $10 \%$ and $15 \% \mathrm{ZnO}$, a spherulitic surface with pinholes (red circles) is verifiable, as presented in Figure 6(b). The preparation methodology used for these compounds (10\% and $15 \% \mathrm{ZnO})$ must be improved, pinholes should not exist in films intended for food packaging as their presence prevents the proper food packing. Also, Figure 6(c) shows ZnO aggregates on the film surface, which is indicative of a poor dispersion that can be linked to the lower residue content measured by TG. These films possess zones with higher and lower $\mathrm{ZnO}$ concentrations. Figure 6(d) is an amplification of $\mathrm{ZnO}$ aggregates displayed in Fig. 6(c). At high $\mathrm{ZnO}$ concentrations, the particles appear to be untied to the film surface.

According to the literature, the $\mathrm{ZnO}$ bactericidal effect reaches $98 \%$ efficacy at $1 \%$ concentration; at concentrations higher than $1 \%$, only few improvements are observed. With the methodology applied in this work, films with well dispersed $\mathrm{ZnO}$ particles are prepared for $\mathrm{ZnO}$ contents up to $5 \%$, thus with a satisfying bactericidal effect for proper food packing [10-12].

\section{CONCLUSIONS}

PCL and PCL/ZnO films were produced by solution processing; adding ZnO to PCL decreased its thermal stability and increased PCL crystallinity. From MO images $\mathrm{ZnO}$ may be considered as a nucleating agent during the PCL crystallization; a higher amount of smaller spherulites was observed for PCL/ZnO compounds. According to SEM images, homogeneous PCL/ZnO films were successfully prepared for $\mathrm{ZnO}$ contents up to $5 \%$.
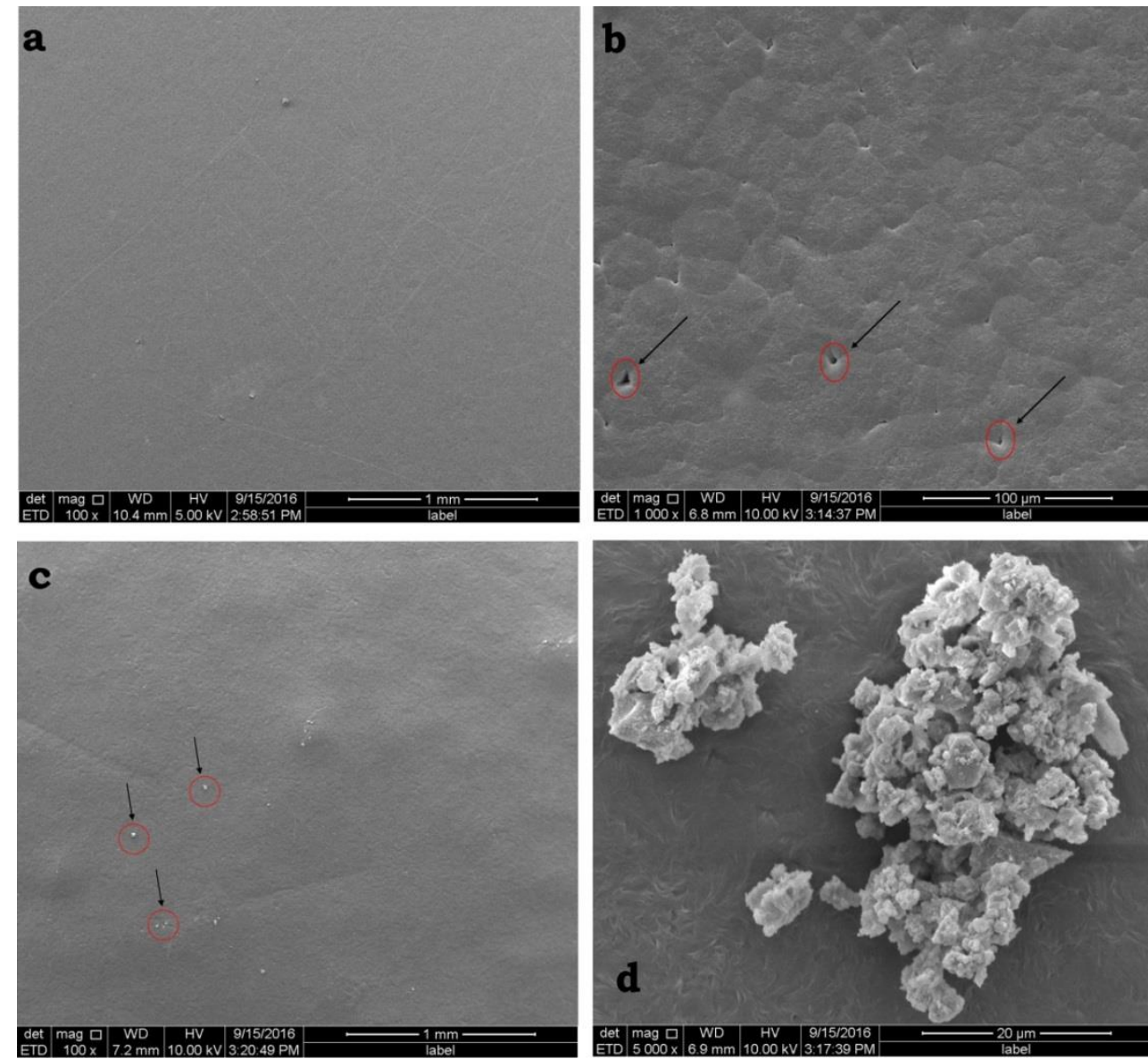

Figure 6: SEM images for PCL/5\%ZnO (a), PCL/15\%ZnO (b), PCL/15\%ZnO (c), amplification of red circles showed in (c) for PCL/15\% ZnO (d). 


\section{ACKNOWLEDGEMENTS}

NGJ would like to thank CNPq (Conselho Nacional de Desenvolvimento Científico e Tecnológico) for his fellowship, and AR to CAPES (Coordenação de Aperfeiçoamento de Pessoal de Nível Superior) for his postdoctoral fellowship.

\section{BIBLIOGRAPHY}

[1] WU, W., WANG, W., LI, J., "Star polymers: Advances in biomedical applications ”, Progress in Polymer Science, v. 46, pp. 55-85, 2015.

[2] PERTICI, G., Bioresorbable Polymers for Biomedical Applications. Introduction to bioresorbable polymers for biomedical applications. Elsevier Press, Cambridge, pp. 3-29, 2017.

[3] SAFRANSKI, D.L., GRIFFIS, J.C., "Mechanical properties of shape-memory polymers for biomedical applications", In: Shape Memory Polymers for Biomedical Applications, $1^{\text {st }}$ ed., Elsevier, pp. 9-33, 2015.

[4] FORTUNATI, E., PULIGA, D., ARMENTANO, I., et al., "Multifunctional antimicrobial nanocomposites for food packaging applications”, In: Food Preservation, pp. 265-303, 2017.

[5] LIU, H., HUANG, Y., YUAN, L., et al., "Isothermal crystallization kinetics of modified bamboo cellulose/PCL composites”, Carbolydrate Polymers, v. 79, pp. 513-519, 2010.

[6] ZHURAYLEV, E., SCHMELZER, J.W.P., WUNDERLICH, B., et al., "Kinetics of nucleation and crystallization in poly(e-caprolactone) (PCL)", Polymer, v. 52, pp. 1983-1997, 2011.

[7] JIANG, S., JI, X., AN, L., JIANG, B., "Crystallization behaviour of PCL in hybrid confined environment”, Polymer, v. 42, pp. 3901-3907, 2001.

[8] RIGHETTI, M.C., DI LORENZO, M.L., ANGIULI, M., et al., "Poly(butylene terephthalate)/poly( $(\varepsilon-$ caprolactone) blends: Influence of PCL molecular mass on PBT melting and crystallization behavior”, European Polymer Journal, v. 43, pp. 4726-4738, 2007.

[9] LV, Q., WU, D., QIU, Y., et al., "Crystallization of Poly( $\varepsilon$-caprolactone) composites with graphite nanoplatelets: Relations between nucleation and platelet thickness", Thermochimica Acta, v. 612, pp. 25-33, 2015.

[10] DIEZ-PASCUAL, M., DEZ-VICENTE, A.L., "Poly(3-hydroxybutyrate) / ZnO bionanocomposites with improved mechanical, barrier and antibacterial properties", International Journal of Molecular Science, v. 17, pp. 10950-10973, 2014.

[11] YU, W., LAN, C., WANG, S., et al., "Influence of zinc oxide nanoparticles on the crystallization behavior of electrospun poly(3-hydroxybutyrate-co-3-hydroxyvalerate)nanofibers”, Polymer, v. 51, pp. 24032409, 2010.

[12] PADMAYATHY, N., VIJAYARAGHAVAN, R., "Enhanced bioactivity of ZnO nanoparticles - an antimicrobial study", Science and Technology of Advanced Materials, v. 9, n. 3, art.-no. 035004, 2008.

[13] MANDELKERN, L., Crystallization of Polymers, v. 1: Equilibrium Concepts. 2nd Edition. Cambridge University Press, Cambridge (UK), p. 249, 2002.

[14] MANDELKERN, L., ALAMO, R.G., “Thermodynamic Quantities Governing Melting”, pp. 165-186, In: MARK, J.E. (ed.), Physical Properties of Polymers Handbook, 2nd Edition. Springer, Berlin, 2007.

[15] VAN KREVELEN, D.W., NIJENHUIS, K.Te., Properties of Polymers, 4th Edition, Elsevier, p. 21, 2009. 